\title{
The Wellcome Greek Collection
}

\author{
Petros Bouras-Vallianatos
}

The Library at Wellcome Collection houses nearly 9,000 manuscripts in about twenty-five different languages, such as Greek, Latin, Arabic, Armenian, Ethiopic, Persian, Sanskrit, Malay, Mongolian, Tibetan, and Korean, dating from antiquity to the modern period. ${ }^{1}$ The Greek collection is one of the smallest, comprising a few papyri fragments and sixteen manuscripts, including some extraordinary examples. Among the papyri is the so-called Johnson Papyrus, one of the earliest surviving fragments from an illustrated

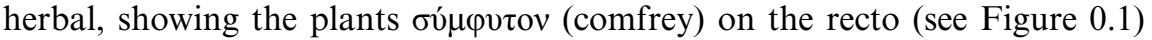

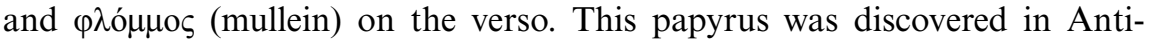
noöpolis, on the east bank of the Nile in Egypt, and is dated to the early fifth century AD. ${ }^{2}$ Among the Wellcome papyri is also the earliest surviving (fragmentary) witness of the Hippocratic Oath itself (P.Oxy. XXXI 2547), found in Oxyrhynchus, $160 \mathrm{~km}$ southwest of Cairo, and dated to the late third/early fourth century $\mathrm{AD}^{3}$

The Greek manuscripts date from the fourteenth to the eighteenth centuries and the academic community worldwide has not been very familiar with this material until very recently. Following the publication of the first descriptive catalogue in $2015,{ }^{4}$ this volume aims to make some important examples from the Greek collection more widely known by providing specialised studies on particular texts in these manuscripts. In this introduction, I shall give a critical overview of the contents of all the Greek manuscripts and at the same time I shall point out the contributions made

1 Many of them have been digitised. Medieval and early modern digitised manuscripts are available at https://wellcomelibrary.org/collections/browse/collections/digwms/(accessed, 20 October 2019).

2 Wellcome shelfmark: MS.5753. See Marganne (2001: 3-4) with references to earlier bibliography.

3 Wellcome shelfmark: MS.5754. On this, see Leith (2017: 40-1). On its importance for the reconstruction of the Greek text of the Oath, see the discussion in the most recent critical edition by Jouanna (2018: lxxxviii-xciv).

4 Bouras-Vallianatos (2015). See also pp. 181-2 in this volume for three brief additions/corrections to the catalogue. 


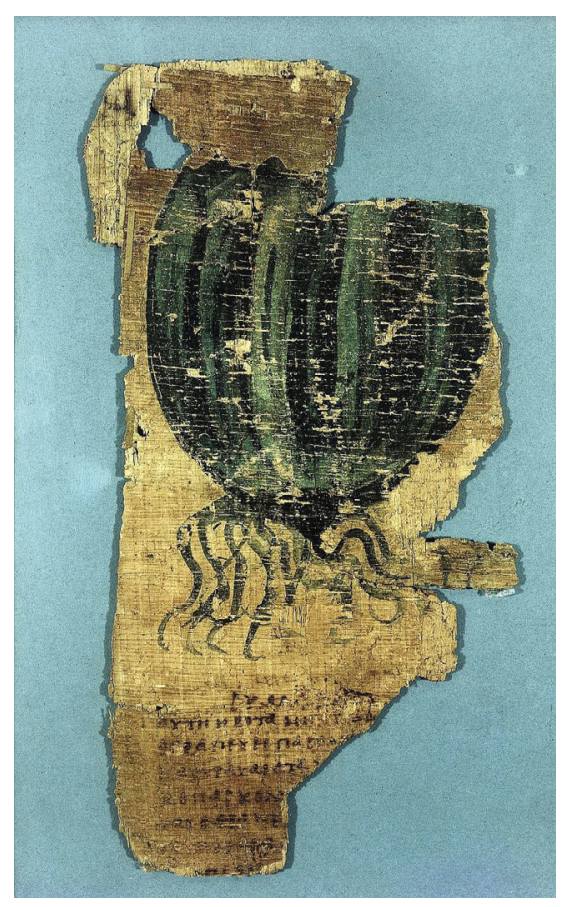

Figure 0.1 Johnson Papyrus, recto. Illustration of comfrey.

(C) The Library at Wellcome Collection, London.

by the various chapters, which will hopefully constitute the starting point for further study and examination of this hitherto neglected group of Greek codices. I shall take a chronological approach, starting from the earliest codices.

Vivian Nutton (Chapter One) provides a vivid account of the creation of the Wellcome Greek collection, the previous owners of the manuscripts, and how they were finally purchased by the Library. Among the sixteenthcentury manuscripts, we can distinguish two groups. The first contains eleven manuscripts (i.e. MS.MSL.1, 14, 52, 60, 62, 109, 112, 114, 124, 126, and 135) and was first collected by the English physician and bibliophile Anthony Askew (1722-74), who had an excellent knowledge of both Greek and Latin. Askew's collection was subsequently owned by another physician, James Sims (1741-820), before he sold it to the Medical Society of London in 1802. It only became part of Wellcome Collection in the 1980s, thanks more especially to the efforts of the Wellcome Librarian Noel Poynter (1908-79) and the first Director of the Wellcome Institute Peter Williams (1925-2014). There are also another five codices (MS.289, 354, 413, 498, and 4103) that were bought separately between 1901 and 1936, i.e. in the 
lifetime of the American pharmacist and avid collector of artefacts, Sir Henry Wellcome (1853-936).

The earliest manuscripts in the collection are MS.MSL.114 and MS. MSL.14. MS.MSL.114 contains a complete copy of Paul of Aegina's (fl. first half of the seventh century) Epitome, a seven-volume medical handbook dealing with dietetics, fevers, and diseases arranged in a capite ad calcem (from head to toe) order, dermatology, bites of venomous animals and antidotes for poisons, surgery, and pharmacology. ${ }^{5}$ The manuscript was copied around $1335-45$ by George Chrysokokkes. ${ }^{6}$ Several later hands have added recipes in the margins of the last few folia with text (ff. 195r-197v) and the entire main area of f. 198r-v, which would suggest that it was once owned by medical practitioners (see Figure 0.2). Due to difficulties in dating and identifying hands, there has been no research into the anonymous recipes that appear in significant numbers in Byzantine manuscripts. These recipes can improve our understanding of easily procurable drugs and daily practice in the medieval and early modern Eastern Mediterranean Greek world. Among the examples in MS.MSL. $114,{ }^{7}$ there are mentions of various

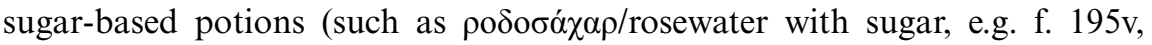

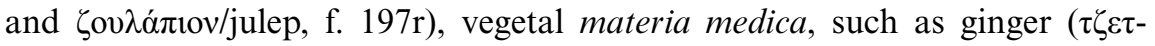

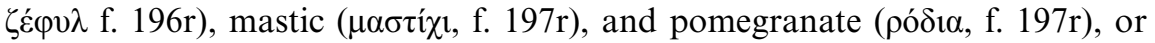
less common animal substances, such as excrement of eagle and hawk

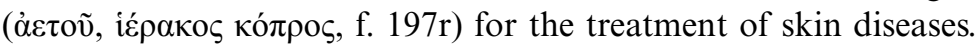

One of the most interesting manuscripts of the collection is MS.MSL. $14 .^{8}$ This is a tiny medical codex consisting of two distinct parts and dated to the first half of the fourteenth century. It is mainly made up of various collections of diagnostic, prognostic, and therapeutic advice for daily use. Barbara Zipser, who has previously provided the first edition of John Archiatros' Iatrosophion, the longest text in this manuscript, ${ }^{9}$ edits and translates into English a brief collection of diagnostic and therapeutic recommendations on pp. 76-81 in the first part of her study (Chapter Three). Zipser shows that some of the recipes coincide with John Archiatros' Iatrosophion (version $\omega$ ) and are also very similar to the collections of recipes associated with Byzantine xenons, the so-called xenonika ${ }^{10}$ One can see recipes for the treatment of fevers, various kinds of haemorrhages, earache, and vomiting. Vegetal substances are by far the most often cited ones, including, for example, aloe, wormwood, and myrtle. One could note, for example, the use of the mineral substance Lemnian earth for the treatment

\footnotetext{
5 Ed. Heiberg (1921-4).

$6 R G K$ III 126, in which the scribe is identified with the well-known astronomer George Chrysokokkes. On the debatable nature of this identification, cf. Mondrain (2012: 631-2).

7 Bouras-Vallianatos (2015: 309-10).

8 Bouras-Vallianatos (2015: 283-6).

9 Ed. Zipser (2009: 173-329, version $\omega$ ).

10 On these texts, see Bennett (2017).
} 


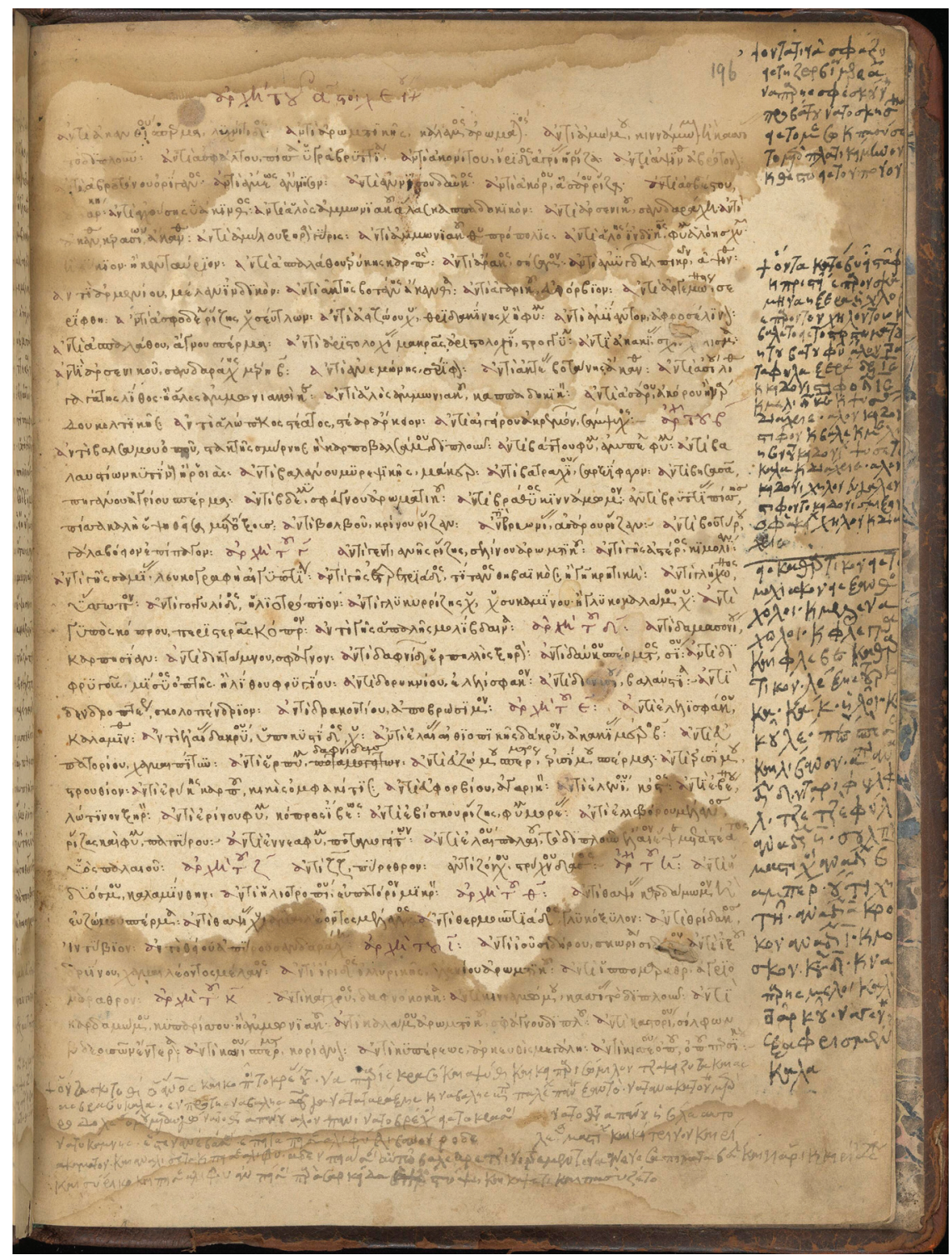

Figure 0.2 Londiniensis Wellcomensis MS.MSL.114, f. 196r.

(C) The Library at Wellcome Collection, London.

of dysentery. Lemnian earth was a famous ancient and medieval panacea mineral drug, the strong anti-bacterial effect of which has been recently identified by a group of scholars in Glasgow, based on analysis of 
a sixteenth-century sample. ${ }^{11}$ In another case, smoke from the burnt skin of a hedgehog is applied to the groin of someone suffering from strangury, in addition to bloodletting. There are also recipes of a cosmetic nature, such as the use of boiled base horehound with wine for halitosis. In the second part of her chapter, Zipser discusses some excerpts from pp. 84-107, where, apart from the recommendation of drugs and brief diagnostic details, one occasionally finds details with magical and religious elements, indicating the large variety of approaches to healing that were available in the Middle Ages and also to the interrelationship between them.

Tina Lendari and Io Manolessou (Chapter Four) offer the first comprehensive linguistic analysis of the language of Byzantine and post-Byzantine iatrosophia, basing themselves on MS.MSL.14 and MS.4103 and showing their importance as invaluable sources in the understanding of the history of the development of the Greek language. They argue that the language of MS.MSL.14 displays a middle register of Medieval Greek, including an important number of archaic elements. One can find some innovative elements of nominal inflection in this version of John Archiatros' Iatrosophion, such as the inflectional class of feminine nouns (e.g. $\dot{\alpha} \lambda \omega \pi \mathrm{o} \tilde{\varsigma})$ and innova-

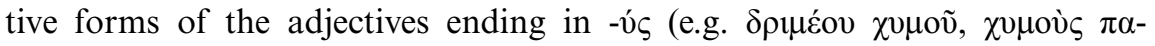
$\chi \varepsilon$ covs). In terms of vocabulary, the absence of loanwords from Italian and Turkish is notable, pointing to an early date. MS.MSL.14 is also the earliest known text in which a number of Medieval Greek words appear, such as $\dot{\alpha} \beta \gamma о v ́ \tau \sigma ı \kappa o v, \gamma \alpha i ̈ \delta \alpha ́ \rho \alpha$, and $\varphi \alpha \gamma \omega ́ v o \mu \alpha$. In the second part of the manuscript (pp. 272-317), which preserves an interesting set of diagnostic details involving the examination of urines and the pulse as well as therapeutic instructions, often including superstitious connotations, there are several lowregister elements. But, as in the first section of the manuscript, the text should not be considered dialectical and thus a particular dialectical origin cannot be determined.

Next comes MS.354 of which the first part was written in the first quarter of the fifteenth century and which preserves two Hippocratic texts that were circulated widely in the medieval period, i.e. Aphorisms and Prognostic. ${ }^{12}$ The first of these is presented here together with a commentary on it by the fifth-century scholar Damaskios. Each aphorism is followed by the relevant

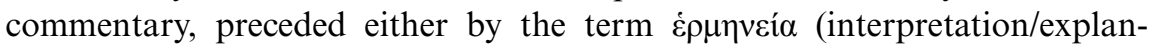
ation) or $\sigma \chi 0$ ó $10 \mathrm{~V}$ (interpretation/comment) in magenta red ink, showing the reader where each comment starts and thus creating a user-friendly mise-enpage (see Figure 0.3). The second part of the manuscript is of later date (AD 1582-7) and preserves a commentary by the sixth-century scholar Stephen on the Hippocratic Prognostic. It was copied by a well-known

11 Photos-Jones et al. (2018).

12 Bouras-Vallianatos (2015: 317-18). 


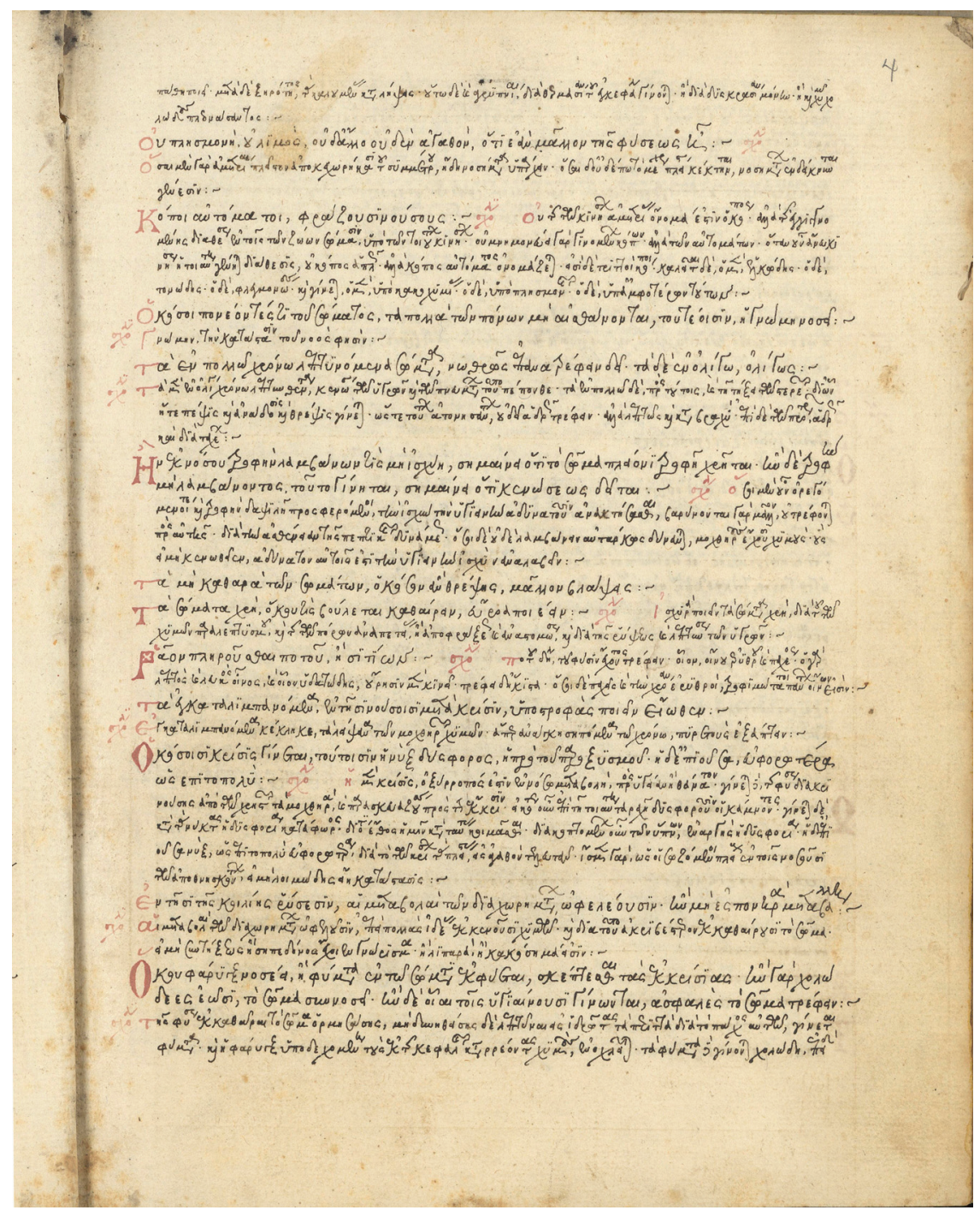

Figure 0.3 Londiniensis Wellcomensis MS.354, f. 4r. (C) The Library at Wellcome Collection, London.

sixteenth-century Greek scribe, Andreas Darmarios, who worked in Italy, Germany, and Spain. ${ }^{13}$

$13 R G K$ I 13, II 21, III 22. On this scribe, see Elia (2014). 
One of the longest manuscripts is certainly MS.MSL.52, which consists of two volumes, 52A and 52B, bound separately, but foliated continuously. ${ }^{14}$ $52 \mathrm{~B}$ is made up of two distinct parts, 52B1 and 52B2. 52A and 52B1 were copied by the physician and scribe Demetrios Angelos ${ }^{15}$ before 1463 and contain the medical corpus of the late Byzantine physician John Zacharias Aktouarios (ca. 1275-ca. 1330). John made several important innovations in the fields of human physiology, pharmacology, and uroscopy, including the introduction of a graduated urine vial that became extremely popular in the Renaissance West after the translation of his On Urines into Latin by Leo of Nola (1458/9-1525) in 1519. ${ }^{16}$ A diagram of John's urine vial has been drawn in the margin of f. 54r. As in other manuscripts already mentioned, here too we can see recipes added by later hands, including one for a julep for the dissolution of kidney or bladder stones by the otherwise

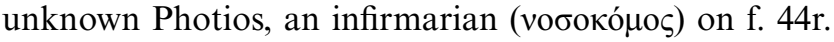

52B2 was copied around 1445 and transmits inter alia diagnostic excerpts from Paul of Aegina's Epitome and Aetios of Amida's Tetrabiblos on the pulse, Galen's On the Pulse for Beginners, and Ps.-Galen's On Procurable Remedies. The longest work in this part is the so-called Anonymus Parisinus, On Acute and Chronic Diseases, which took its name from the first manuscript discovered of this treatise, which was found in Paris, viz. Parisinus suppl. gr. 636 (sixteenth century). The Wellcomensis manuscript contains twenty-nine of the fifty-one sections of the text. This treatise is of great significance since it is one of the very few Greek medical texts to survive from the period between the late fourth century $\mathrm{BC}$ and the second century AD (i.e. the Hellenistic and Roman periods). It thus provides a window onto the progress made in medical theories, especially as regards acute and chronic diseases, between the composition of the Hippocratic corpus (fifth-fourth century BC) and Galen (AD 129-216/17). Orly Lewis (Chapter Two) provides a detailed analysis of the text in light of the development of ancient medical concepts relating to aetiology, symptomatology, and therapeutics, including the role of pneuma. Among the most important developments emphasised here is the notion of the 'affected part', viz. the particular part(s) of the body to be treated, which was developed in postclassical medicine. Even more interesting is the wide range of therapeutic recommendations that one finds in the Anonymus Parisinus, including various techniques of bloodletting, externally and internally applied drugs, cuppings, diet, exercise, or even the use of amulets, as well as the distinction between curative and restorative treatment. There is also interesting information on how physicians tested different therapeutic agents on a particular

14 Bouras-Vallianatos (2015: 286-92).

15 Mondrain (2010). See also Database of Byzantine Book Epigrams, s.v. Demetrios Angelos, at www.dbbe.ugent.be/persons/695 (accessed, 20 October 2019).

16 Bouras-Vallianatos (2020: 205-14). 


\section{Petros Bouras-Vallianatos}

patient, thus showing the importance of feeding medical practice with empirical observations. All in all, Lewis argues that the work must have been written as a 'handbook' for practising physicians, encapsulating the author's theoretical knowledge in combination with his rich practical experience.

MS.MSL.60 is a large medical miscellany consisting of several brief texts with a diagnostic, prognostic, and therapeutic focus, some collections of recipes, and a few astrological opuscules, including some tables on the computation of the date of Easter (see Book Frontispiece) ${ }^{17}$ It is dated to the second half of the fifteenth century and is clearly connected with contemporary medical practice in the Eastern Mediterranean. For example, one can see informal marginal annotations, including comments on the use of particular simple and composite drugs mentioned in the manuscript, ${ }^{18}$ or even synonyms for plant substances in Greek and Turkish. ${ }^{19}$ There are also recipes, occasionally added by later hands on blank pages or in the blank space left between the end of one treatise and the beginning of another ${ }^{20}$ Its contents include excerpts from the Hippocratic Aphorisms and Prognostic, Symeon Seth's Treatise on the Capacities of Foodstuffs, Theophilos' works on fevers, urines, and the pulse, Demetrios Pepagomenos' recipe book, and an anonymous, unedited medical compilation on diagnosis and therapy on ff. $73 \mathrm{r}-124 \mathrm{v}$. There are also several brief prognostic and diagnostic treatises attributed to Arab and Persian physicians, indicative of the high degree of pluralism in the material available in late Byzantium, where Greek and Byzantine medical knowledge was interwoven with imported Arabic medical lore, especially from the twelfth century onward. ${ }^{21}$ Another closely related text is a noteworthy bilingual glossary of plant names (f. 71v) in Greek and Arabic (in Greek transliteration), intended to facilitate the introduction of Greek readers to the oriental materia medica that had entered Greek medical literature and practice through translations of medical works from Arabic into Greek. ${ }^{22}$

Another fifteenth-century manuscript is the MS.498 dated to $1492 .{ }^{23} \mathrm{It}$ contains various poems, including autograph epigrams on the Virgin Mary and Christ by a teacher of the Patriarchal School in Constantinople and notable theologian Manuel Korinthios (ca. 1460-1530/1), as well as

17 Bouras-Vallianatos (2015: 292-302).

18 See, for example, the long annotation on $\mathrm{f}$. $129 \mathrm{v}$, which refers to the effectiveness of a certain

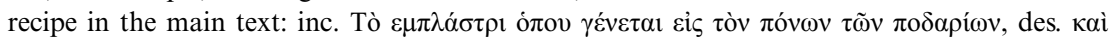

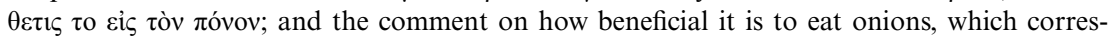
ponds to the relevant chapter in Symeon Seth's dietetic treatise: $\tau \alpha \kappa \rho o \mu i ́ \delta 1 \alpha v \alpha \tau \alpha \beta \rho \alpha \xi \eta \varsigma v \alpha$

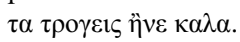

19 E.g. f. 79r: '

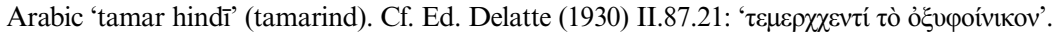

20 Of the various recipes added by later hands, the most notable example is an excerpt from

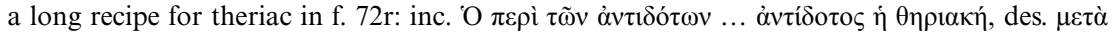

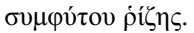

21 For a recent critical overview of Arabo-Byzantine medical translations, see Touwaide (2016).

22 Ed. Serikoff (2013).

23 Bouras-Vallianatos (2015: 321-4). 
a collection of astronomical works. Maria Tomadaki (Chapter Six) focuses on the eight poems found in the manuscript, providing the first critical edition, English translation, and commentary. Seven of the poems have acrostics, often highlighted in red ink, spelling out either Manuel's name or his

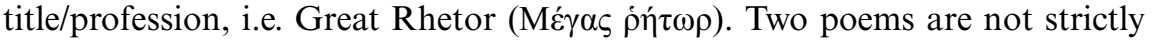
theological in nature; one laments the vanity of life and the other is about the zodiac signs and composed in heptasyllables. The latter is particularly interesting since there is a clear attempt by the unknown author to Christianise the popular subject of astrology. It also alludes to the astronomical content of the manuscript, which is discussed by Anne Tihon (Chapter Five). The longest part of the manuscript transmits the Byzantine adaptation of the Jewish treatise Shesh Kenaphayim (the Six Wings), composed by Immanuel Bonfils around 1350, which is an important testimony to the introduction of Jewish astronomy into late Byzantium. The text is ascribed to the otherwise unknown Byzantine author, i.e. Michael Chrysokokkes notarios of the Great Church, and was written around 1435. The Greek title is Hexapterygon, which is a literal translation of the Hebrew version. It was a particularly popular text/treatise in the Greek-speaking Mediterranean, surviving in about fifteen manuscripts, including two anonymous adaptations and a sixteenth-century commentary. It mainly consists of various astronomical tables (each called a ' $\Pi \tau \varepsilon \rho$ óv$^{\prime} /$ Wing) concerning the calculation of various celestial phenomena, such as syzygies and eclipses. On the basis of some medallions with depictions of the zodiac signs, Tihon shows that the Wellcomensis version is most probably based on codex no. 188 of the Holy and Great Monastery of Vatopedi on Mount Athos.

The Library at Wellcome Collection also owns a group of three medical manuscripts that were copied separately in the first half of the sixteenth century in Italy. They show no signs of substantial use or any significant annotations by later hands, apart from some notes on variant readings. They transmit texts by Aretaeus of Cappadocia, Rufus and Ps.-Rufus of Ephesus (MS.MSL.62), Aetios of Amida (MS.MSL.109), and Ps.-Galen (MS.289). ${ }^{24}$ Their importance as textual witnesses is yet to be determined since they have not so far been used for the production of critical editions of the relevant texts. MS.MSL.135 is a sixteenth-century manuscript that originated in the Eastern Mediterranean. ${ }^{25}$ It transmits the medical corpus of the Byzantine medical author Theophanes Chrysobalantes and Symeon Seth's Treatise on the Capacities of Foodstuffs. The codex also includes a significant number of recipes added by various later hands and annotations commenting on or supplementing the contents of the main text.

24 Bouras-Vallianatos (2015: 302-7, 316-17).

25 Bouras-Vallianatos (2015: 314-16). 
The collection contains four seventeenth-century manuscripts, i.e. MS. MSL.1, MSL.124, MSL.126, and MS.4103. ${ }^{26}$ Arguably, the most interesting is MS.MSL.1, a collection of philosophical texts in the Aristotelian tradition together with some exercises for learning Greek that were used for the education of Greek-speaking students in the seventeenth century. Nikos Agiotis (Chapter Seven) provides a meticulous study of the various texts, revealing some interesting connections concerning the transmission and appropriation of Greek translations of commentaries by Renaissance Latin authors, including the hitherto unknown Greek translation of the Spanish Jesuit Francisco de Toledo's (1532-96) widely circulated Latin work on Aristotelian logic Commentaria una cum quaestionibus in universam Aristotelis logicam. Agiotis presents further evidence attesting to a possible connection between the collection of texts in this codex and the Collegio Greco di Sant'Atanasio, the Greek educational institution in Rome, which was administered by Jesuits for almost two centuries (1591-1604, 1622-1773). Thus, the Greek translation must have been a useful companion for Greek students beginning their studies there, who had very little knowledge of Latin, the otherwise official language of education in the Collegio Greco.

MS.MSL.124 and MSL.126 together with the eighteenth-century codex MS.MSL. $112^{27}$ are copies of medical texts by Oribasios (Medical Collections) and John Zacharias Aktouarios (On Urines and Medical Epitome) made from manuscripts that were found in England. The first two were copied from Cambridge manuscripts, while the third is a direct copy from MS.MSL.52, most probably commissioned by Anthony Askew himself. The enduring interest in John Zacharias Aktouarios among early modern physicians can be explained by the production of the sixteenth-century Latin translations of his corpus, which became influential in Western Europe.

MS.4103 consists of a collection of iatrosophia combined with texts of an often superstitious nature on divination, dream interpretation, astrological opuscules, and texts on thunders (brontologia) and earthquakes (seismologia) written in vernacular Greek. Tina Lendari and Io Manolessou (Chapter Four) confirm in their detailed linguistic study of the codex the obvious 'Northern vocalism', thus associating the language of the codex with the Northern dialects of Modern Greek. Several other linguistic observations point to more similarities with the dialects of the regions of Epirus and Sterea Ellas. In terms of vocabulary, there are a significant number of loanwords from Italian/Romance and Turkish, and a small number of terms of Slavic, Albanian, or even Aromanian origin. Last, there is one codex, MS.413, which was copied around $1800 .{ }^{28}$ It contains a collection of oracles, ascribed to Emperor Leo VI the Wise (r. 886-912) and Arsenios

26 Bouras-Vallianatos (2015: 279-83, 311-13, 324-6).

27 Bouras-Vallianatos (2015: 307-8).

28 Bouras-Vallianatos (2015: 319-21). 
Markellos, patriarchal secretary in the second half of the sixteenth century. The codex is nicely illustrated by twenty-two drawings in ink and wash. A study of this codex could potentially illustrate some features of the sixteenth-century political milieu in the Ottoman Empire.

\section{Bibliography}

Bennett, D. 2017. Medicine and Pharmacy in Byzantine Hospitals. Abingdon: Routledge.

Bouras-Vallianatos, P. 2015. 'Greek Manuscripts at the Wellcome Library in London: A Descriptive Catalogue', Medical History 59: 275-326.

Bouras-Vallianatos, P. 2020. Innovation in Byzantine Medicine: The Writings of John Zacharias Aktouarios (c.1275-c. 1330). Oxford: Oxford University Press.

Delatte, A. (ed.). 1930. 'Le lexique de botanique du Parisinus graecus 2419', in Serta Leodiensia. Liége and Paris: Vaillant-Carmanne and Champion, 59-101.

Elia, E. 2014. Libri greci nella Biblioteca nazionale universitaria di Torino: $i$ manoscritti di Andreas Darmarios. Alessandria: Edizioni dell'Orso.

Heiberg, J. L. (ed.). 1921-4. Paulus Aegineta. 2 vols. Leipzig and Berlin: Teubner [C.M.G., IX.1-2].

Hunger, H. et al. (eds.). 1981-97. Repertorium der griechischen Kopisten 800-1600. 3 vols in 9 pts. Vienna: Verlag der Österreichischen Akademie der Wissenschaften [cited with volume no. followed by catalogue no., e.g. RGK II 120].

Jouanna, J. 2018. Le Serment. Les Serments chrétiens. La Loi. Paris: Les Belles Lettres.

Leith, D. 2017. 'The Hippocratic Oath in Roman Oxyrhynchus', in M.-H. Marganne and A. Ricciardetto (eds.), En marge du Serment hippocratique. Contrats et serments dans le monde gréco-romain. Liège: Presses Universitaires de Liège, 39-50.

Marganne, M.-H. 2001. 'Livres de médecine illustrés dans l'Egypte gréco-romaine', Medicina nei Secoli 13/1: 1-23.

Mondrain, B. 2010. 'Démétrios Angelos et la médecine: contribution nouvelle au dossier', in V. Boudon-Millot et al. (ed.), Storia della tradizione e edizione dei medici greci, Atti del VI Colloquio Internazionale Paris 12-14 Aprile 2008. Naples: D'Auria, 293-322.

Mondrain, B. 2012. 'La lecture et la copie de textes scientifiques à Byzance pendant l'époque Paléologue', in G. De Gregorio and M. Galante (eds.), La produzione scritta tecnica e scientifica nel medioevo: libro e documento tra scuole e professioni. Spoleto: Fondazione Centro italiano di studi sull'Alto Medioevo, 607-32.

Photos-Jones, E., Knapp, C. W., Venieri, D., Christidis, G. E., Elgy, C., ValsamiJones, E., Gounaki, I. and Andriopoulou, N. C. 2018. 'Greco-Roman Mineral (litho)Therapeutics and their Relationship to their Microbiome: The Case of the Red Pigment Miltos', Journal of Archaeological Science: Reports 22: 179-92.

Serikoff, N. (ed.). 2013. "'Syriac" Plant Names in a Fifteenth Century Greek Glossary (From the Wellcome Library Books and Manuscripts)', in B. Zipser (ed.), Medical Books in the Byzantine World. Bologna: Eikasmos, 97-115.

Touwaide, A. 2016. 'Agents and Agencies? The Many Facets of Translation in Byzantine Medicine', in F. Wallis and R. Wisnovsky (eds.), Medieval Textual Cultures. Berlin: W. de Gruyter, 13-38.

Zipser, B. (ed.). 2009. John the Physician's Therapeutics. A Medical Handbook in Vernacular Greek. Leiden: Brill. 